\title{
Chapter 15 \\ Local Knowledge and Rangeland \\ Protection on the Tibetan Plateau: \\ Lessons for Conservation \\ and Co-management of the Upper \\ Nu-Salween and Yellow River \\ Watersheds
}

\author{
Ka Ji Jia
}

\subsection{Introduction}

The Tibetan Plateau is the source of seven major rivers, including two of the longest rivers in Asia: the Salween and the Yellow River. ${ }^{1}$ As a significant source of fresh water and wetland biodiversity, this area was established as the Three Rivers Source National Nature Reserve, the second largest nature reserve in the world and the world's highest and most extensive protected wetland area (Plateau Perspectives 2014). The Tibetan Plateau is not only a site for water and biodiversity; it is also the center of traditional Tibetan culture, identity, livelihoods, and belief systems. Here, Tibetan herders play an important role in environmental protection, and identify themselves as rangeland protectors and local experts. This chapter explores how herders' livelihoods are connected to the source of the Salween and Yellow Rivers, and how they have responded to environmental change on the Tibetan Plateau.

Land degradation has affected significant parts of China's rangeland including Qinghai Province, the Tibetan Autonomous Region, Inner Mongolia, and the Xinjiang Autonomous Region. Since the early 2000s, the government of Qinghai Province has sought to protect the rangelands from degradation due to 'overstocking,' 'overgrazing' and 'human intervention.' In some cases, this has meant resettlement of Tibetan communities. This chapter examines these terms and practices- i.e., 'overstocking' and 'human intervention' - critically. I also address

\footnotetext{
${ }^{1}$ In Tibetan language, the Salween is known as Gyalmo Ngulchu and the Yellow River is called Ma Chu.
}

Ka Ji Jia, Ph.D. Candidate, Department of Women's Studies, Chiang Mai University; Email: kathytibetan@gmail.com. 
how land degradation based on one form of knowledge, and neglectful of other ways of knowing, poses problems when applied as a standard for all rangeland contexts on the Tibetan Plateau regardless of differing social-economic and cultural contexts. Herders on the Tibetan Plateau have different interpretations of land degradation (Yeh 2003) based on their local knowledge, livelihoods, and geographic location. Land degradation from the perspective of herders is not only caused by 'overgrazing', but also by removing people and their knowledge from the land, as well as by introducing market interventions such as mining activities and land commercialization.

My research shows how herders use their local knowledge as a tool to negotiate with various stakeholders in an effort to maintain access to and authority over their natural resources in the face of a dominant discourse that places blame for land degradation on local resource users (Yeh 2003). I do this by examining local herders' daily life experiences and life stories alongside broader practices of governance on the plateau. I argue that Tibetan herders use their local knowledge as a form of cultural capital (Bourdieu 1986) to negotiate their relationship with the land, both in everyday life and in relation to outside actors, in order to protect their rangelands and cope with the impacts of development projects on their lives and livelihoods.

I include herders' perspectives on rangeland degradation and environmental conservation projects, and examine the impacts of these projects using qualitative methods. In the following sections, the chapter will address methodology, local herders' traditional knowledge, debates around land degradation, and examples from fieldwork to draw out herders' multiple forms of knowledge and the ways they use this knowledge to negotiate to protect the rangeland and sustain their livelihoods on the Tibetan Plateau.

\subsection{Methods}

This research was conducted over multiple field visits in 2014, 2015, and 2017. In 2014-2015, I focused on a herding community and an ecological resettlement community in Xinghai County near the source of the Yellow River in the Tibetan Autonomous Prefecture in Qinghai Province (Site 1). In 2017, I conducted further research at the source of the Salween River in the Tibetan Autonomous Region (Site 2). Both sites (see Fig. 15.1: Map of study sites 1 and 2 in the Tibetan Plateau) are located at the headwaters of different rivers, and the shared cultural and historical practices of the herders includes a shared cosmology of the surrounding environment. This cosmology has helped them to formulate their own cultural capital. Under the same cosmology, herders use their cultural capital in different ways according to their local contexts. While the scope and scale of the research conducted in both sites varied, the overall research project relied on qualitative methods, including informal and semi-structured interviews, personal observation, and group discussion. 


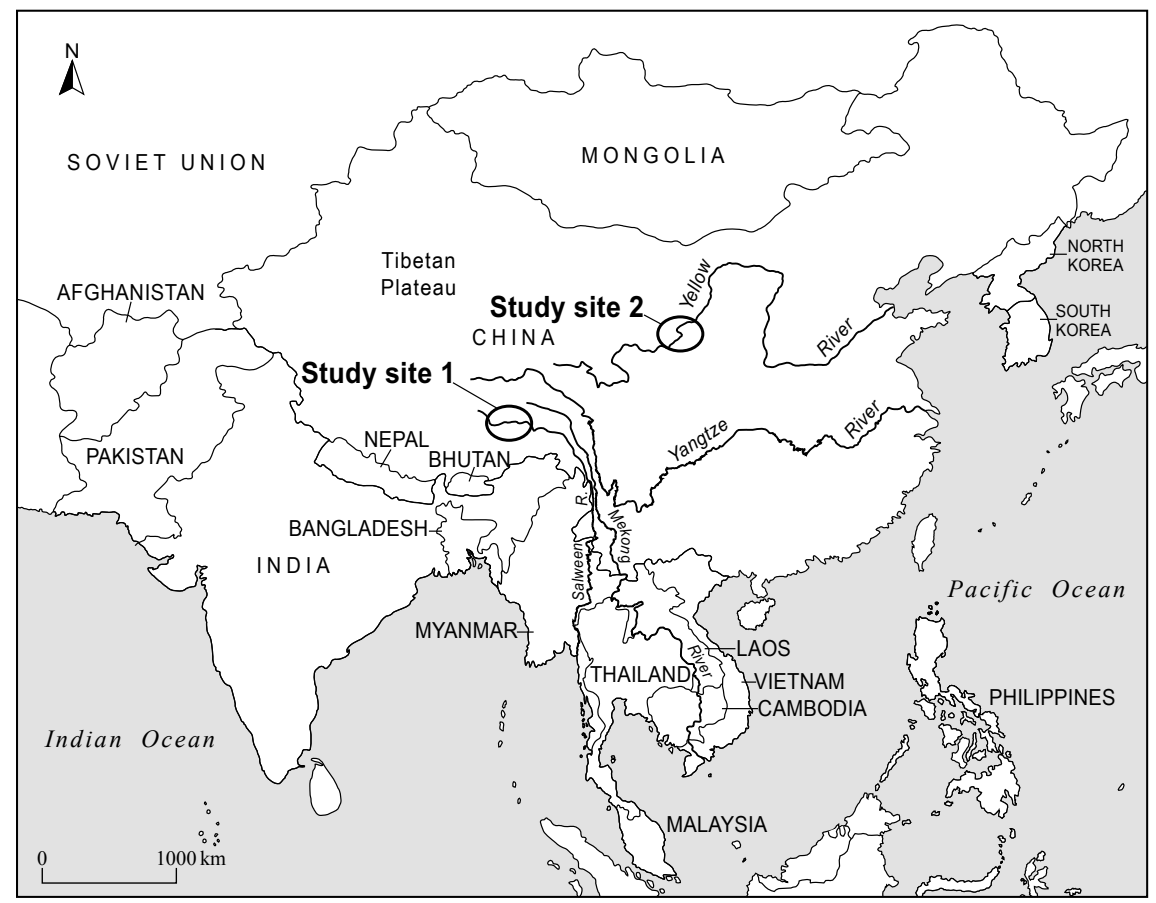

Fig. 15.1 Map of study sites 1 and 2 in the Tibetan Plateau. Source Cartography by Chandra Jayasuriya, University of Melbourne, used with permission

In total, I conducted 15 interviews, and I introduce these data relying on pseudonyms to protect the privacy of individual interviewees. At Site 1, over the course of 4 trips and 60 days, I conducted semi-structured interviews and open question interviews with 10 herders from a herding community relocated under an eco-resettlement project. Interviews were conducted in Tibetan language (Amdo dialect). I also held two group discussions with male and female herders on their rangeland separately. Research at the Yellow River Site focused on herders' local knowledge and how they use their local knowledge as 'cultural capital' to negotiate with various actors.

Building on my fieldwork at Site 1, I carried out a more targeted visit to the Salween River (Site 2). I spent 15 days in a town conducting five semi-structured interviews along with participant observation. At this site, the research focused specifically on herders' belief systems as a form of local knowledge that connects their worldview/cosmology with their environment.

Bringing the interviews and observations from these two sites together in this chapter, I present a range of approaches to understanding livelihoods and conservation on the rangeland. 


\subsection{Study Sites}

The population estimates for the Tibetan population range from 6 to 7 million. There are three subgroups of Tibetan people who, according to their Tibetan dialects, reside in three regions: Amdo, Kham and U-Tsang. In these three regions, the people practice Tibetan Buddhism, and their religious beliefs are closely tied to nature. This has resulted in a strong environmental protection ethos that inspires people to take care of their natural resources including the water, land, mountains and animals. The two study sites are in Qinghai province and the Tibetan Autonomous Region.

At Site 1, most residents speak the Amdo dialect (see Fig. 15.1: Map of study sites 1 and 2 in the Tibetan Plateau). The community I visited is comprised of 305 households, in addition to a resettled community of 200 households. Here, local people practice Tibetan Buddhism, and the main economic activity is herding.

The second site, Sok Dzong (Su Xian County in Chinese), is a semi-herding county located at the source of Salween River, where local people speak Kham and U-Tsang dialects. According to local herders, this county is named after the Sok River, a tributary of the Salween. Here, the local people practice Tibetan Buddhism. Local livelihoods depend on wheat, potatoes, radish, beans and livestock such as yaks, sheep, goats, horses, and cows.

At present, communities across both sites also depend on caterpillar fungus, a native herb that is extracted for commercial purposes, and which I discuss below as a point of tension in the context of shifting livelihoods and environmental management strategies.

For these communities, as with the majority of Tibetan people, animal husbandry is a key livelihood activity. Livestock are generally animals that are resistant to extreme cold, and include sheep, yaks, horses, camels, and goats. Yaks are especially well adapted to extreme cold, and one third of the world's yak population live on the Tibetan Plateau (The Peoples Government of Qinghai 2007). Traditionally, Tibetan herders graze yaks, sheep, horses, goats and cows on the rangeland. These animals produce milk, cheese, butter, meat, and yogurt as food for herders. Herders also shear animals and use the wool to make Tibetan robes to wear in the winter. Even if a sheep or goat is killed by 'natural' causes, such as by wolves or in a snowstorm, the herders use the sheep and goatskins to make clothing, including robes, shoes, and hats. Tibetan herders give human names to their livestock and treat them as human beings. The children of herders play with young livestock and form intimate friendships with them. Herders even bring baby animals to eat and sleep with them if they feel that extra care is needed.

As I discuss further below, a number of changes have impacted herders' livelihoods, including a new property rights regime. Prior to the 1990s, rangeland on the Tibetan Plateau was managed through a common property rights regime. Local herders' livelihood activities were mainly for subsistence, and there was little to no direct involvement in the market. They raised animals for their own family consumption and exchanged excess products within their networks. After the 
1990s, rangeland was placed under a private property regime, which helped herders to link their economy to the market. Today the market plays a vital role.

Tibetan herders maintain strong Buddhist and animist belief systems that involve worship of local deities including sacred mountains, animals, rivers, and trees. This belief system is linked to the Tibetan approach to livestock and animals in general. Tibetans show respect by not taking anything from sacred areas (Tsering 2006). For example, herders do not dig for gold, kill aquatic animals, cut trees, or hunt wild animals in sacred areas. Their environment and livestock not only have economic value, but also cultural and religious meaning. Tibetan herders free some of their livestock as part of religious activities and to show respect for local deities. Those freed livestock are considered holy animals and belong to local deities, and no herders will hurt or kill them. With this close connection to their animals, herders traditionally use a barter system for food rather than direct sale, and this includes exchanging their extra cheese, butter, meat, sheep wool, and yak fur for Tibetan farmers' barley, wheat and canola oil. These livelihood practices reveal a local knowledge significant for survival on the Tibetan Plateau.

Having introduced the study sites and the basics of Tibetan herder livelihoods and beliefs, in the next section I will address land degradation as defined by different actors and how these definitions tend to overlook Tibetan cultural and religious practices, including livestock rearing practices. I further explore how herders identify and define land degradation on their own terms.

\subsection{Debating Land Degradation: Building on Political Ecology}

The mainstream view of land degradation within the Chinese rangeland context is referred to in terms of desertification, overstocking, overgrazing and climate change (Yeh 2003; Nelson 2006). In particular, mainstream researchers perceive of 'overstocking' and 'overgrazing' as the main contributors to rangeland degradation in the highlands of China (Banks 2001: 718). Consequently, they place the blame on herders for severe pasture degradation (Yeh 2003: 505). While some researchers argue that rangeland degradation derives from rural reform dating back to the $1970 \mathrm{~s}$ and that no 'tragedy of the commons' existed in commonly managed rangelands prior to this time (Banks 2001), policy makers claim that 'overstocking' results from unclear property rights on commonly managed rangelands. Various environmental conservation projects have been based on the assumption that herders' ignorance of proper pasture management has led to countless rodent infestations and overgrazing, resulting in infertile land and loss of productivity (Yeh 2003: 505).

As one approach to halting land degradation, some scholars (Liyu/Duoji 2008; Yu 2011; Niu 2011) have put forward strategies for conserving the rangeland. For example, they suggest that relevant authorities enhance the Grazing Ban Policy, which would prohibit herding in particular areas, reduce livestock numbers, 
establish protected areas, and eradicate the pika, a small rodent native to the rangeland (Liyu/Duoji 2008; Yu 2011; Niu 2011). Further suggestions (Liyu/Duoji 2008; Yu 2011; Niu 2011) include that fencing be introduced in order to allow for 'permanent rest' of the rangeland, which effectively means that the rangeland will be fenced in and thus not open for herders and livestock. This is linked to the assumption that to conserve the rangeland, 'human movement' and 'overgrazing' in the rangeland must be reduced. This has led to the resettlement of herders, as seen in the Eco-Resettlement Project in Site 1. Under the Eco-Resettlement Project, the state guaranteed long-term compensation subsidies to resettled people, with mixed results, as I describe below. Projects aimed at conservation have thus negatively impacted herders' livelihoods and property rights. This has stemmed from the application of one uniform theory of 'overstocking' in China, a theory which has failed to consider much of the research carried out to better understand 'land degradation' issues at different sites (Banks 2001; Harris 2010; Du 2012; Dkon mchog dge legs 2012; Dpal ldan chos dbyings 2012). As Wu et al. explain (2015: 11),

It has been concluded in many studies that rangeland degradation associated with overgrazing and climate warming has increased the vulnerability of Tibetan livelihoods ( $\mathrm{Li}$ and Huang 1995; Ma et al. 1999; Sheehy 2001; Zhou et al. 2003; Klein et al. 2004, 2007; Wang et al. 2006, 2007; Li et al. 2007; Shang and Long 2007; Fan et al. 2010; Harris 2010), and policies like rangeland privatization and ecological resettlement has caused uncertain consequences. Some of them also have accelerated the degradation of pastoral ecosystems on the [Qinghai-Tibetan Plateau].

As a result, they argue, “it is important to understand local people's views on how pastoral systems have been impacted by recent social, environmental and political changes and what actions and strategies they have undertaken to cope with these changes" (Wu et al. 2015: 11). Likewise, in examining sacred knowledge in Southwest China, Xu et al. (2005: np) "suggest that the long-term viability of the environment requires an interactive approach that involves local people as well as governments in the creation of environmental policy."

In this chapter, I aim to consider how herders' livelihoods are linked to the land and their access to land in particular pastoral contexts. Changes in land access not only impact herders' livelihoods, but also their local knowledge. Their knowledge is not static and unchanging; it is mixed with scientific knowledge within dynamic localized contexts wherein herders reinforce their local knowledge with outside information, and utilize their local knowledge as a form of cultural capital in negotiation with various stakeholders. Thus, to approach this, I draw on scholarship on local knowledge (Berkes 1999; Santasombat 2004; Xu et al. 2005) in addition work by Bourdieu (1986), who sees knowledge, culture, and various forms of negotiations and community networks as a kind of 'capital' built out of everyday life.

According to Bourdieu (1986), capital is accumulated in labor and through embodied forms. Capital takes time to accumulate and has a potential capacity to produce profits and to reproduce itself in identical or expanded forms. Capital in this sense means not only economic capital, but also other forms of capital 
including cultural capital, symbolic capital, and social capital. This could include exchange (such as trading) to expand networks, gain property rights, create space to negotiate with relevant actors, and exercise power. Social groups establish cultural capital from symbolic capital, which through social recognition legitimizes their knowledge (Bourdieu 1986). For example, a group of people with the same cultural background may inherit certain knowledge from their ancestors, but they also accumulate their own local knowledge through their everyday life practices. All of these knowledges and practices help to formulate their identities and help them to negotiate with others.

In some instances, Tibetan knowledge and practice is overlooked, while in others, Tibetan herders use their symbolic capital of mountain deities and other deities as cultural capital, which through social recognition legitimizes their local knowledge. They use cultural capital as a tool to negotiate with the different actors in their lives to benefit from and protect their natural resources.

In thinking about standard state approaches to land degradation, I examine the overlooked role of local knowledge in relation to Tibetan herders' livelihoods and their approaches to conservation of the plateau. In some instances, herders' local knowledge is indeed successfully used as a form of 'cultural capital' to push forward their own goals and insights into rangeland conservation, for instance, in their negotiations against mining on the rangeland.

In the following section, I describe the importance of local knowledge and local beliefs to Tibetan herders. This is a largely understudied topic, particularly as it relates to the Salween River on the Tibetan Plateau.

\subsection{Herders' Local Knowledge and Practices}

Local knowledge plays a vital role in determining how Tibetan herders promote cultural ecosystems on their rangelands and build harmony between nature and humans. As Miller (2008: 1) explains,

[Tibetan nomads] have an intimate knowledge of their environment and an amazing ability to handle animals - a skill rare amongst most people today ... Nomads' lives are finely tuned to the growth of grass, the births of animals and the seasonal movement of their herds ... [they] have developed a close connection to the land and the livestock that nurture them.

Within traditional cosmology, culture and belief systems, Tibetans believe that mountains and rivers are deeply related to their lives. As explained above, mountains and rivers are sacred places where resident deities protect humans and other living beings. If nature is harmed, local deities are offended and this results in harm to human and animal populations. Therefore, when Tibetans celebrate religious festivals, harvest crops, or when someone needs to leave their community, Tibetans go to worship the deities and ask for their blessings (Tsering 2006). Consequently, Tibetan herders' local knowledge of resource management is directly connected to their belief system. At both the Salween and Yellow River sites, the Tibetan 
herders' cosmology is rooted in Tibetan Buddhism. Tibetan herders have different ways of practicing their religious activities, and they use this local knowledge as a form of cultural capital to support land protection. Tibetan herders worry that natural disasters, land degradation, and declines in vegetation/species are signs telling them that the local deities have been offended by their incorrect behavior and disrespect. In the next section, I provide examples of local knowledge along the Salween and Yellow Rivers on the Tibetan Plateau.

\subsubsection{Salween Deities and the Spiritual Significance of the Land and River}

The local informants from the Salween River Site, Sok Dzong, see land, mountains, animals, and rivers as all connected to their lives. According to interviewees, their belief system influences their cosmology and daily practices. As one interviewee, Mr. Karma, referred to the earth: "a female monster is sleeping here. The earth is like our mother. She is sleeping. If we offend her by polluting "Sok Chu" [the Salween River] and destroying the environment, she will wake up and become a devil and harm local people" (Personal conversation, June 2017). Furthermore, interviewees noted the ways they use religious activities to show their respect for local deities. For example, Mr. Karma explained that:

When "Kar ma rak shi" [a special star] appears in the sky, we clean our horses in the waters of the Sok Chu [Salween], because during that time the river water becomes 'medicinal,' so our horses will not get illnesses. Also, on special days like the eighth of every month, we offer food to the fish in the Sok Chu [Salween River] (Interview in Sok Dzong, June 2017).

In this county entire communities, including girls, boys, men and women, also participate in religious activities like "Ma ni ser zam," which embody Tibetan cultural links with nature. When a community member passes away, the Ma ni ser zam ceremony helps the dead go to heaven. During the ceremony, small white stones and sand are used to write "Ma ni ser zam" on the ice once the river freezes over. Local people believe that when they do this on frozen rivers, the river becomes a bridge to help the deceased go to heaven. In this way, people pay respect to rivers, and regard them as special and sacred sites. This kind of activity shows how local beliefs and practices connected to death are linked to rivers. Such beliefs are part of the local knowledge system embodied within Tibetan culture, which denies the dualistic idea that nature is separate from human society. The fact that local Tibetan herders see themselves and their belief system as linked to nature invokes Berkes' assertion that belief plays an essential role in traditional ecological knowledge (Berkes 1999).

At the Yellow River Site, the Tibetan community has a similar belief system, which sees all living beings as equal to humans, and views some areas as sacred, including the highest mountains and largest rivers. In these sacred areas, local deities also exist. At the Salween River Site, the locals also believe in the existence 
of deities, and people at both sites commonly believe that offending deities may bring bad luck to individuals, families, or the community. The mining of minerals from a sacred mountain areas is considered a particularly offensive action for mountain deities. According to local beliefs, minerals belong to mountain deities, and the disrespect to deities shown by mining companies brings bad luck. Local communities thus see the establishment of sacred areas as a way to protect their natural resources.

\subsection{Research Findings on Local Knowledge as Cultural Capital to Negotiate for Natural Resource Management}

Building on their local knowledge and experience, Tibetan herders at both sites play important roles in environmental protection, and identify their local knowledge as a resource - in some instances, I argue that it becomes a kind of 'cultural capital' - to negotiate with various actors in order to maintain access and authority over the rangeland. With increased land degradation, these local practices are being challenged and misrepresented as contributing to degradation instead of protecting land and livelihoods. This tension-preservation of the plateau, traditional livelihoods, and land degradation - is at the center of this paper's interrogation of rangeland conservation protection debates. The three examples provided in the next section will show how Tibetan herders use local knowledge in natural resource management, and will explore some of the livelihood changes that herders are experiencing on the plateau as they struggle to maintain their land governance practices.

\subsubsection{Tensions Between Experimental Zones, the "Holy Mountain," and Mining}

Land use and land ownership on the plateau have changed for herders. There have been three shifts in land rights and management that are important to understand in the current context of natural resource management in the area. The rangeland has seen a transition from collective management of livestock on state-owned property to common property managed by villagers to the situation today where herders are granted individual, private property rights. As Nori et al. (2008: 11) argue "The institutional environment of Tibetan herders offers an eloquent example of how policy trends can adversely affect pastoral societies."

In short, in 1953, at the beginning of Chairman Mao's era, the local government in Xinghai County established herding sites for different livestock and hired herders to collectively herd livestock under a collective system. Herders were paid a monthly wage of around 60-70 RMB (10 USD), and were provided meals. The 
herders mainly raised sheep, yaks, cows, and horses on their own herding sites, and all of the livestock belonged to the state until 1956. This was a marked shift from Tibetan herder societies' customary management system, as although "land management had traditionally been communal, livestock were in fact household property" (Nori et al. 2008: 11). Private property as such ceased to exist during this time.

A second transformation came in 1956, when land reform was rolled out by the state at the national level. Property relations changed from a collective system of livestock management to a common property system with communal livestock (on communal land). Villagers on the plateau were able to manage the land until China's Open-Door Policy in 1978. From that time onwards, most of the communal land was divided into individual household plots and was privatized. In herding communities like the Yellow River Site, herders told me that they practiced this system, and that most communal land had been divided into households under privatization, which grants individual households land use rights.

Thirdly, by the 1990s, most communal land was divided into households under privatization, which meant that individuals had rights to manage or use their own land. Nori (2004) also explains how these property shifts led to a change in relations around the market and trade through state-controlled mechanisms (the quota system), and that market forces play a major role in reshaping local livelihood today.

Along with this shift to private property rights for individual and family land plots, resource extraction activities such as mining, and the rights to minerals, were also introduced under the private property system. The private property system allowed for the 'sale' of property, and allowed companies to access individual herders' land. Mining activities not only affected local livelihoods, but also weakened local collective power over land, land management and ecological sustainability.

These land governance and ownership changes, along with the introduction of mining, have impacted both herders' livelihoods and rangeland ecology. Interviewees told me that 40 years ago, grasses on the rangeland grew so tall that they could not see their sheep. This kind of phenomenon no longer exists. While herders attribute such changes to both climate change and mining activities, it was clear that when the mining companies began operating on the rangeland, it negatively impacted the grasses. For instance, after mining companies upgraded roads on the mountains, many small-scale deserts appeared. The quality of rangeland worsened and the environment became polluted by mining activities. With increasingly less rainfall and inadequate grasses on the rangeland (Wu et al. 2015), herders now have to buy grass to feed their livestock from people with few or no livestock on their land.

One interviewee explained,

Mining has not only affected our area, but also people throughout our province, even the whole country. When companies take out minerals from the mountains like the holy mountain Amyi Rma Chin, these mountains are left with only their skins, but are empty inside, like a dead person who only leaves his corpse (Interview with XH3, Yellow River Site, March 2014). 
Underlining the severity of the impacts, he explained further, "rivers have been contaminated, the fish are dead, and the mountain has collapsed."

Land privatization and the introduction of mining have not just led to environmental impacts; local culture has also been affected. Herding communities have responded to these impacts in a range of ways. Communities express various forms of open or hidden resistance. In these silent struggles, herders use their belief system, incorporating holy mountains, holy rivers and local deities as 'cultural capital' to access rights to natural resource management and to negotiate with various stakeholders to gain legal support for their claims.

A key example involves Amyi Rma Chin, a holy mountain that is well-known in Tibetan areas. This holy mountain is connected to herders' lives; local herders explain that the place where they live is Amyi Rma Chin's table, meaning that the holy mountain and their rangeland cannot be separated. However, local herders are suffering impacts from a large-scale copper mining project. With the project's establishment in 2001, the mining company told herders that they will help herders by building roads, creating jobs, and providing considerable payments. However, several years after the mining company began operations, local herders found that the company did not fulfil their promise. The herders also realized that the mining company had caused negative impacts on their rangeland, livestock, health, and belief system. For example, the mining company gradually expanded the area of their operations. This has caused a lot of sand to appear on the rangeland, the mountain has collapsed, and livestock have been negatively affected by tailings in the river and on the grasslands. Local herders report being affected by air pollution, and are concerned that their holy mountain has been damaged.

In response, herders have publicly reclaimed Amyi Rma Chin as a holy mountain, noting that the damage to Amyi Rma Chin is an offensive action against their religious beliefs.

Amyi Rma Chin is a place revered by the herders who believe that the mountain is master and protector of the area, and as such, will protect the lives of those who live in its presence. Amyi Rma Chin is also the herders' seasonal summer home and pastureland. Herders have not 'taken from' the holy mountain's rich store of mineral resources, as it is linked to their beliefs that it is a sacred place.

In addition, herders use their belief system to influence relevant laws in such a way that legitimizes their local knowledge. For instance, herders are making a case that their herding location belongs to a state experimental zone, ${ }^{2}$ and in this experimental zone, mining activities are prohibited. One herder, Mr. Dorji, explained that herders can live in the experimental zone, and that even though the state encourages herders to limit their livestock numbers, and some land must be fenced in as protected land (where herding is not allowed), the establishment of the zone also means that mining operations are prohibited.

\footnotetext{
${ }^{2}$ There are a variety of "experimental zones" across China. They are not all the same, with different policies and different practices. I have explained here how local people see it, but it is not always entirely clear.
} 
As a result of these community efforts, in 2017, local herders received legal support from the government, and mining in the experimental zone was permanently stopped. The herders used symbolic power to build collective solidarity and mobilize their community to protect the holy mountain.

These local efforts to engage with the mining company were not without effort and tension. There were different voices among the herders, with some herders supporting mining activities because, although they saw the mine's impacts on their livelihoods, they were able to access certain benefits. In order to build solidarity at the community level, the majority of herders not only focused on land rights and livestock, but also used their common belief in Amyi Rma Chin to mobilize the whole community to protect the holy mountain. This shows how herders built internal solidarity by using the symbolic power of the mountain as a sacred site, and this symbolic power became the cultural capital that enabled them to negotiate with the mining company.

In reflecting on these changes, some herders state that the common rangeland management system of the past was more efficient in protecting rangeland ecology than the current privatized rangeland management system. This is not only because of the impacts of mining. Some herders also experienced resettlement (discussed next), and some have resorted to allowing digging for previously sacred caterpillar fungus on their land in order to make money to support their families (discussed in the following section). They suggest that the common rangeland management system of the past enabled them to control their livestock size and make decisions based on what the land could support, and was not based on commercial or market forces. However, under the current private rangeland management system, there is an incentive for herders to make money by selling their livestock or allowing outsiders to use their rangeland.

\subsubsection{Eco-resettlement as Alternative Livelihood}

Through interviews with resettled herders and my own observations, I found that although there are some benefits to resettlement in terms of educational opportunities and limited subsidies, resettlement does not present a viable alternative livelihood. I found no evidence that resettlement furthers the aims of conservation, as it removes the herders and their care of the rangeland from the Tibetan Plateau.

Resettlement at the Yellow River Site began in 2005, when villages were moved under the state-sponsored "Eco-resettlement Project." The Eco-resettlement Project aimed to protect the rangeland and improve the livelihoods of local herders. However, it has created unintended consequences for herders' livelihoods, and most herders choose not to live in resettlement sites, as they are aware that the resettlement project cannot bring them sustainable livelihoods. Those living in resettled communities experience difficulties, such as water and electricity shortages, lack of jobs, discrimination, and lack of support for cultural practices. 
Moreover, through interviews, resettled herders explained that resettlement is not an adequate solution to environmental protection. One herder explained, "resettlement was supposed to protect our environment, right? But I'm not sure whether that's the right way to protect it." (Interview XH2, Yellow River Site September 2013). Across interviews, herders' comments highlighted the link between their roles as herders and environmental protectors. Herders felt that the outcomes of resettlement were contrary to the initial objectives of the project, which aimed to improve rangeland protection and herders' livelihoods in the face of what was perceived as severe rangeland degradation at the Three Rivers Source on the Tibetan Plateau.

Visiting the resettlement areas, I could meet only with the elderly and children. From my interviews with older herders, I learned that herders had resettled here because of a shortage of labor (lack of young people) to maintain their pastures and livestock. They required help from young people to manage their pastures, but most children had been sent to schools outside the community. In some cases, there were no young people in the family. According to herders experiencing labor shortages, resettlement was an alternative livelihood that would allow them to receive subsides from the local government. For example, government subsidies may include: support for children under 16 years old and for adults over 55 years old (hence the make-up of the resettlement community). They may also include: land subsidies depending upon the size of land, winter fuel subsidies, housing subsidies, and peasant household subsidies. However, these subsidies have not always improved living conditions. As one interviewee explained,

\footnotetext{
When we resettled here, I thought there were no improvements to the environment and also our living conditions got worse. Our house is of really bad quality, and water often comes inside after it rains. I've had to rebuild my house three times and every time I've had to spend 4,000-5,000 RMB. In total I've spent 12,000 RMB from my savings (Interview XH6, Yellow River Site, September 2013).
}

Some resettled herders have been able to find alternative means of livelihood, such as working in construction, collecting caterpillar fungus (described below), and opening small shops. Many resettled herders, however, are not happy with their current life.

I am not satisfied with my current life. I cannot find a job due to my physical condition, so I have no income- only expenses. For example, I took out loans from the bank for my child's education. In fact, I came here just for my child's education. Otherwise I would prefer to stay in my original house. (Interviewee XH2, Yellow River Site, September 2013)

Children's education was a main reason that herders provided for why they followed the eco-resettlement project. My informants claimed that they were voluntarily resettled, and that it was not permanent resettlement. Most of them explained that they led two ways of life. They would sometimes go back to their herding areas and sometimes come to the resettlement area. It was completely dependent on their own decision. However, in resettling, they also faced many social problems such as difficulty finding jobs, and lack of access to clean water, electricity and health care. One former herder explained, "I've been doing nothing 
since I resettled here and my wife is gravely sick. Everything here I need to buy with money, such as water, electricity, meat and vegetables" (Interview XH5, Yellow River Site, September 2013). And another former herder said, "After I resettled here, my living conditions got worse. For example, I had cheese, butter, and milk before resettlement, but now I have none of these things to eat." (Interview XH2, Yellow River Site September 2013). Or as another interviewee explained, "I feel that pastoral life is better than resettled life here. Before, I didn't need to buy meat, butter, potatoes or other vegetables" (Interview XH6, Yellow River Site, September 2013). Their comments also underline the links between their pastoral livelihoods and the life satisfaction in their communities.

These aspects of "eco-resettlement" complicate standard assumptions that removing herders from the landscape will support environmental protection. In my analysis, this case also shows that herders rely on certain silent struggles and negotiations, as they may receive benefits from the eco-resettlement project, even as they may continue to try to practice pastoral livelihoods and do not fully support the project. In doing so, the majority of herders still keep their land and livestock as cultural capital in response to the resettlement project.

Moving forward, another alternative livelihood practice that has emerged is collection of the once-sacred caterpillar fungus. I consider this practice and the way it both relies on and impacts 'cultural capital' in the next section, drawing on work across the two research sites.

\subsubsection{Caterpillar Fungus and Livelihood Change}

The "Sok Chu" or Salween River Site is a main area for the collection of caterpillar fungus due to its high-altitude location. Local residents depend on a mixed set of livelihood activities. Here, a number of changes have led Tibetan herders to stop herding livestock, particularly sheep, due to frequent encroachments from feral dogs and wolves. Local people practice another form of livelihood based on their own cultural capital, that is access to caterpillar fungus. This practice represents a way for Tibetan herders to make a living in an increasingly difficult situation. It also represents a shift in local beliefs, for in the past, caterpillar fungus was not collected - it was considered sacred. According to local legend, Tibetans believe that caterpillar fungus is a female deity's braid. Because they saw caterpillar fungus as a holy plant, Tibetans did not eat or dig the caterpillar fungus for any purposes. Today, Tibetans have mixed feelings about collecting the product: "The opinions recorded varied between seeing it as an innocent activity not entailing any guilt and as a digpa [a sin or negative karma]" (Sulek 2016: 8).

Caterpillar fungus (Ophiocordyceps sinensis), known locally as 'Yar tsa gun bu', literally means 'summer grass winter worm.' It has been used widely in China since the 1990s (Shrestha/Bawa 2013). The caterpillar fungus boom is related to China's rapid economic growth; people believe that caterpillar fungus is a medicine that strengthens the lungs and kidneys and increases energy and vitality 
(Holliday/Cleaver 2008: 225). Since the 1990s, the caterpillar fungus trade has been linked to national and global markets, and the fungus can be found in Nepal, Bhutan, and China (Tibet). In Tibetan areas, caterpillar fungus is mainly found at between 3,500 and 5,000 $\mathrm{m}$ altitude in Tibet (TAR), Qinghai, Sichuan, Gansu and Yunnan. It is mainly collected in Naqu and Changdu in Tibet, and Yushu and Guoluo in Qinghai (Xuan 2012). According to Tibet's Agriculture and Herding Office, in 2012, "150,600 people collecting the fungus in Naqu [District] harvested 16.3 tonnes -3.7 tonnes less than the year before." Caterpillar fungus is declining, as it could be found above $3,500 \mathrm{~m}$ in the past, but can now only be found above 4,500 $\mathrm{m}$ (China Dialogue 2012). With the rise of the caterpillar fungus economy, Tibetan people's subsistence-based livelihoods have been altered in ways that pose further uncertainties.

Reasons for this shift towards collection, what some have termed the "caterpillar fungus boom" (Sulek 2016: 3; see also: Yeh/Lama 2013), include the rise in demand, better links to the market, and the shift in land ownership and control. While caterpillar fungus was not a commercial product in the past, with the introduction of a market-oriented economy on the plateau, caterpillar fungus has become a commercial product with high market value, and is collected on both private and common land. In some instances, herders abandon livestock production if they can earn enough from collecting caterpillar fungus, freeing all of their livestock except some for family consumption. Or as Sulek explains,

The income from caterpillar fungus has made the pastoralists less dependent on pastoral production. They adjusted to the new situation by breeding fewer sheep and reducing the sale of dairy and other products. They also reduced the number of yaks sold for commercial slaughter (2016: 10).

The collection of caterpillar fungus is not only done by local herders, but also by outsiders. The outsiders are usually from other places in China. The local herders with land containing caterpillar fungus often hire diggers from other areas or rent their land to businessmen. The diggers might be Tibetans (famers and herders), Han Chinese, Muslim Chinese, and others. The diggers' backgrounds are very diverse and most of them may not have environmental protection awareness or may not want to take care of the land. In this case, local landowners and local people complain that the diggers do not protect the land as local people do.

Residents also link the history of state responses to livestock rearing to the rise of caterpillar fungus. At the Salween Site, for instance, the state introduced wire fences in many areas in order to limit the mobility of wild animals. The fence project affected wild animals' reproductive behavior, and the local food chain. This was all done with the goal of rangeland protection. However, this also had impacts on the herders' livelihoods. Herders reported that the feral dog population greatly increased, and that feral dogs often attacked herders' sheep, raising great concerns for their livelihoods. To respond to this, the herders have had to stop grazing sheep. This is another reason why they are increasingly turning to caterpillar fungus harvesting. The reduction of livestock numbers on the rangeland by both individual 
herders and conservation projects has resulted in feral dogs and wolves attacking other endangered animals like gazelle in the conservation areas.

In this case, I saw how local herders are drawing on their local knowledge to harvest caterpillar fungus in a way that is dynamic and responds to the local context. I also saw that many herders have had to stop grazing sheep due to wild animals' frequent encroachment onto their land, which is linked to state efforts to protect and 'fence in' the rangeland. While the ecosystem imbalance and increasingly market oriented economy pushes herders to stop herding, they draw upon their own cultural capital to access caterpillar fungus to maintain their livelihood.

\subsection{Discussion and Conclusion}

Tibetan herders from both the Salween and Yellow River sites share ethnic and geographical identities, livelihoods, beliefs and an overall cosmology that places them in a central position to protect nature and the rangeland. At these two study sites, local herders have mobilized these connections, using their cultural capital in the natural resource management process to respond to change and protect the rangeland. This can be witnessed through multiple forms of negotiation, strategies, and adaptation under different conservation regimes, property rights schemes, and market interventions.

At the Salween River Site, fences introduced to address ecosystem imbalances pushed herders away from raising sheep due to frequent encroachment by wild animals, however, they established other forms of livelihood based on their local knowledge of nature and landscape, what I see as cultural capital. The caterpillar fungus economy has had some impacts on the ecology, and in some places like Yun Ta village in Yushu Prefecture, Qinghai Province, local Tibetan people have developed their own environmental protection strategies and built strong mechanisms to prevent overharvesting of caterpillar fungus and reduce harms to the environment (Zhao 2015). These strategies are seen not only in the case of caterpillar fungus, but also in the ways herders strategically deployed 'experimental zones' for protection from mining, selectively participated in eco-resettlement projects, and made the conservation of the holy mountain explicit to outsiders. This is how local herders bring their knowledge to negotiate with state knowledge and to produce their own cultural capital.

The research presented here underlines the fact that herders' local knowledge in resource management not only lends a different perspective to the 'overgrazing' debate, but may also inform policy around such issues as mining, wire fencing, commercial harvesting, and climate change. My call to include herders' local knowledge in resource management recognizes the fact that the form this knowledge takes is constantly changing based on location, economic context, and livelihood strategies. Local knowledge is thus not based on one static idea. Herders develop different perspectives and livelihood strategies in response to various uncertainties and unintended consequences. It can be a struggle to work together 
with competing interests, but herders' actions support Yos Santasombat's findings that "knowledge production should be seen as a process of social negotiation involving multiple actors and complex power relations and must therefore be understood in terms of change, adaptation and dynamism" (2003: 43).

I also show the ways in which local knowledge in combination with symbolic culture can be mobilized to negotiate and care for the land, as seen when herders emphasize their holy mountains and local deities. Symbolic culture used as cultural capital can be legitimized to negotiate with relevant stakeholders to improve access to natural resources and seek better livelihood strategies based on individual and community interests.

In many ways, these findings are in line with other scholarship on the Asian Highlands, including a review by Xu/Grumbine (2014: 99) which showed that "In the Asian Highlands, a more integrated approach that blends strategies to secure more resource access for local people could pave pathways toward successful climate adaptation, more inclusive governance, and greater state stability."

However, what I add here are the personal accounts from both the Salween and Yellow River field sites which show how Tibetans' local knowledge is closely connected to their religious beliefs and their environment, reflecting that, "knowledge cannot be divorced from the natural and cultural context within which it has arisen, including their traditional lands and resources and their kinship and community relations" (Higgins-Zogib et al. 2010: 173). Tibetan cultural knowledge has long recognized that without nature, human beings cannot survive; people depend entirely on the earth to live. Similarly, without minerals, the grasslands and mountains will be empty and unable to survive. Projects and practices aimed at conserving the Tibetan Plateau could benefit by incorporating the beliefs and knowledge of herders.

Herders, stakeholders and relevant authorities need to reconsider 'co-management' and 'co-production of knowledge' to develop a shared analysis of rangeland environmental protection strategies. Through this collaborative process, the co-production of knowledge will help local people to meet their own educational, cultural and political needs while improving livelihood strategies and environmental conservation work on the Tibetan Plateau (Berkes 2002, 2009).

\section{References}

Banks, T. (2001). Property rights and the environment in pastoral China: Evidence from the field. Development and Change, 32(4), 717-740.

Berkes, F. (1999). Sacred ecology: Traditional ecological knowledge and resource management. Philadelphia, PA: Taylor \& Francis.

Berkes, F. (2002). The drama of the commons: Cross-scale institutional linkages, perspectives from the bottom up. Washington, DC: National Academy Press.

Berkes, F. (2009). Indigenous ways of knowing and the study of environmental change. Journal of the Royal Society of New Zealand, 39(4), 151-156. 
Bourdieu, P. (1986). The forms of capital. In J. Richardson (Ed.), Handbook of research for the sociology of education (pp. 241-258). Westport, CT: Greenwood.

China.org.cn. (2013). Retrieved from the Sanjiangyuan National Nature Reserve in China's Qinghai website: http://www.china.org.cn/travel/2013-03/06/content_28135757.htm.

Dkon mchog dge legs. (2012). China's pastoral development policies and Tibetan plateau nomad communities. Asia Highlands Perspectives, 18(1), 37-72.

Dpal ldan chos dbyings. (2012). Plateau pika control in Santu alpine grassland community, Yushu Prefecture, Qinghai Province, China. Asia Highlands Perspectives, 18(1), 108-124.

Du, F. (2012). Ecological resettlement of Tibetan herders in the Sanjiangyuan: A case study in Madoi county of Qinghai. Nomadic peoples. Retrieved from: http://www.case.edu/affil/tibet/ tibetanNomads/documents/ecologicalresettlementfortibetanherderinthesanjiangyuan.pdf.

Harris, R.B. (2010). Rangeland degradation on the Qinghai-Tibetan plateau: A review of the evidence of its magnitude and causes. Journal of Arid Environments, 74, 1-12.

Higgins-Zogib, L., Dudley, N., \& Kothari, A. (2010). Living traditions: Protected areas and cultural diversity. In N. Dudley \& S. Stolton (Eds.), Arguments for protected areas: Multiple benefits for conservation and use (pp. 165-188). Abingdon, United Kingdom: Taylor and Francis.

Holliday, J., \& Cleaver, M. (2008). Medicinal value of the caterpillar fungi species of the genus Cordyceps (Fr.) link (Ascomycetes), A review. International Journal of Medicinal Mushrooms, 10, 219-234.

Kumar, K.A. (2010). Local knowledge and agriculture sustainability: A case study of Pradhan tribe in Adilabad district. Center for Economic and Social Studies No. 81. Hyderabad, India: Center for Economic and Social Studies.

Liyu, H.Z., \& Duoji, L. (2008). 青海省海南州三江源区草地退化成因及治理对策 [Qinghai Hainan Prefecture's rangeland degradation and conservation strategies]. 草业与畜牧 Grassland and Animal Husbandry, 2, 49-51.

Miller, D. (2008). Dropka: Nomads of the Tibetan Plateau and Himalaya. Boonsboro, MD: Vajra Publications.

Nelson, R. (2006). Regulating grassland degradation in China: Shallow-rooted laws? Asian-Pacific Law \& Policy Journal, 7(2), 385-417.

Niu，L. (2011). 保护草原生态系统，促进牧区畜牧业可持续发展 [Protection of Grassland Ecosystem and Promotion of Sustainable Development for Animal Husbandry]. 中国畜牧兽医文摘 China Animal Husbandry, 5, 14-15.

Nori, M. (2004). Hoofs on the roof: pastoral livelihoods on the Qinghai-Tibetan Plateau, the case of Chengdu county, Yushu prefecture. Rome, Italy: ASIA-ONLUS. Retrieved from: http:// www.cwru.edu/affil/tibet/booksAndPapers/Hoofs_on_the_Roof.pdf.

Nori, M., Taylor, M., \& Sensi, A. (2008). Browsing on fences: pastoral land rights, livelihoods and adaptation to climate change. IIED Issue Paper, No 148. Retrieved from: http://pubs.iied.org/ 12543IIED/.

Plateau Perspectives. (2014). Sanjiangyuan (Three Rivers' Headwaters) National Nature Reserve $(S N N R)$. Retrieved from the Plateau Perspectives website: www.plateauperspectives.org.

Prasert, T. (2008). Space of resistance and place of local knowledge in Karen ecological movement of northern Thailand: The case of Pgaz K' Nyau villages in Mae Lan Kham River Basin. Southeast Asian Studies, 45(4), 586-614.

Santasombat, Y. (2003). Biodiversity: Local knowledge and sustainable development. Chiang Mai, Thailand: RCSD Chiang Mai University.

Santasombat, Y. (2004) Karen cultural capital and the political economy of symbolic power. Asian Ethnicity, 5(1), 105-120.

Shrestha, U.B., \& Bawa, K.S. (2013). Trade, harvest, and conservation of Caterpillar fungus (Ophiocordyceps sinensis) in the Himalayas. Biology and Conservation, 159, 514-520.

Sulek, E.R. (2016). Caterpillar fungus and the economy of sinning. On entangled relations between religious and economic in a Tibetan pastoral region of Golog, Qinghai, China. Études mongoles et sibériennes, centrasiatiques et tibétaines, 47, 1-17. 
The People's Government of Qinghai. (2007). Beautiful Qinghai. Retrieved from People's Government of Qinghai website: http://www.qh.gov.cn/dmqh/glp/.

Tsering, B. (2006). The changing roles of Tibetan mountain deities in the context of emerging environmental issues: Dkar po lha bsham in Yul Shul. Asian Highlands Perspectives, 40, 1-33.

Wu, X., Zhang, X., Dong, S., Cai, H., Zhao, T., Yang, W., Jiang, R., Shi, Y., \& Shao, J. (2015). Local perceptions of rangeland degradation and climate change in the pastoral society of Qinghai-Tibetan Plateau. The Rangeland Journal, 37(1), 11-19.

$\mathrm{Xu}$, J., \& Grumbine, R.E. (2014). Integrating local hybrid knowledge and state support for climate change adaptation in the Asian Highlands. Climatic change, 124(1-2), 93-104.

Xu, J., Ma, E.T., Tashi, D., Fu, Y., Lu, Z., \& Melick, D. (2005). Integrating sacred knowledge for conservation: cultures and landscapes in southwest China. Ecology and Society, 10(2), 7.

Xuan, C. (2012, March 9). How long can the caterpillar fungus craze last? China Dialogue. Retrieved from: https://www.chinadialogue.net/article/show/single/en/5143-How-long-canthe-caterpillar-fungus-craze-last.

Yeh, E.T. (2003). Tibetan range wars: Spatial politics and authority on the grasslands of Amdo. Development and Change, 34(3), 499-523.

Yeh, E.T., \& Lama, K.T. (2013). Following the caterpillar fungus: nature, commodity chains, and the place of Tibet in China's uneven geographies. Social \& Cultural Geography, 14(3), 318-340.

Yu，H. (2011). 青海省天然草地退化现状及可持续发展策略 [The situation of Qinghai's degraded natural grassland and sustainable development strategies]. 中国畜牧兽医文摘 China Animal Husbandry, 5, 14-15.

Zhao, X. (2015). 云塔村的虫草一一来自基层的管理逻辑 [Yun Ta village's caterpillar fungus from local management logic]. Retrieved from Shan Shui Conservation Center website: http://www.shanshui.org/ArticleShow.aspx?id=264.

Open Access This chapter is licensed under the terms of the Creative Commons Attribution 4.0 International License (http://creativecommons.org/licenses/by/4.0/), which permits use, sharing, adaptation, distribution and reproduction in any medium or format, as long as you give appropriate credit to the original author(s) and the source, provide a link to the Creative Commons license and indicate if changes were made.

The images or other third party material in this chapter are included in the chapter's Creative Commons license, unless indicated otherwise in a credit line to the material. If material is not included in the chapter's Creative Commons license and your intended use is not permitted by statutory regulation or exceeds the permitted use, you will need to obtain permission directly from the copyright holder. 